\title{
Successfully Executing Ambitious Strategies in Government: An Empirical Analysis
}

\section{Citation}

Kelman, Steven, and Jeff Myers. 2009. Successfully Executing Ambitious Strategies in Government: An Empirical Analysis. HKS Faculty Research Working Papers RWP09-009, John F. Kennedy School of Government, Harvard University.

\section{Published Version}

http://web.hks.harvard.edu/publications/workingpapers/citation.aspx?Publd=6563

\section{Permanent link}

http://nrs.harvard.edu/urn-3:HUL.InstRepos:4481609

\section{Terms of Use}

This article was downloaded from Harvard University's DASH repository, and is made available under the terms and conditions applicable to Other Posted Material, as set forth at http:// nrs.harvard.edu/urn-3:HUL.InstRepos:dash.current.terms-of-use\#LAA

\section{Share Your Story}

The Harvard community has made this article openly available.

Please share how this access benefits you. Submit a story.

Accessibility 


\author{
Faculty Research Working Papers Series
}

\title{
Successfully Executing Ambitious Strategies in Government: An Empirical Analysis
}

\author{
Steven Kelman \\ John F. Kennedy School of Government - Harvard University
}

\section{Jeff Myers}

Booz Allen Hamilton Inc.

\section{April 2009}

RWP09-009

The views expressed in the HKS Faculty Research Working Paper Series are those of the author(s) and do not necessarily reflect those of the John F. Kennedy School of Government or of Harvard University. Faculty Research Working Papers have not undergone formal review and approval. Such papers are included in this series to elicit feedback and to encourage debate on important public policy challenges. Copyright belongs to the author(s). Papers may be downloaded for personal use only. 
SUCCESSFULLY EXECUTING AMBITIOUS STRATEGIES IN GOVERNMENT: AN EMPIRICAL ANALYSIS

\author{
Steven Kelman \\ Harvard University \\ John. F. Kennedy School of Government \\ Jeff Myers \\ Booz Allen Hamilton Inc.
}




\title{
SUCCESSFULLY EXECUTING AMBITIOUS STRATEGIES IN GOVERNMENT: AN EMPIRICAL ANALYSIS
}

\begin{abstract}
How are senior government executives who attempt to execute an ambitious vision requiring significant strategic change in their organizations able to succeed? How do they go about formulating a strategy in the first place? What managerial and leadership techniques do they use to execute their strategy? In this paper, these questions are examined by comparing (so as to avoid the pitfalls of "best practices" research) management and leadership behaviors of a group of agency leaders from the Clinton and Bush administrations identified by independent experts as having been successful at executing an ambitious strategy with a control group consisting of those the experts identified as having tried but failed at significant strategic change, along with counterparts to the successes, who had the same position as they in a different administration. We find a number of differentiators (such as using strategic planning, monitoring performance metrics, reorganizing, and having a smaller number of goals), while other techniques either were not commonly used or failed to differentiate (such as establishing accountability systems or appeals to public service motivation). We find that agencies that the successes led had significantly lower percentages of political appointees than the average agency in the government. One important finding is that failures seem to have used techniques recommended specifically for managing transformation or change as frequently as successes did, so use of such techniques does not differentiate successes from failures. However, failures (and counterparts) used techniques associated with improving general organizational performance less than successes.
\end{abstract}


How are senior government executives who attempt to execute an ambitious vision requiring significant change in their organizations able to succeed? How do they go about formulating a strategy in the first place? What managerial and leadership techniques do they use to execute their strategy? In this paper, these questions are examined by comparing management and leadership behaviors of a group of agency leaders from the Clinton and Bush administrations (1993-2007) identified by independent experts as having been successful at executing a strategy involving an ambitious vision and significant organizational change with a control group consisting of those identified as having tried but failed at significant strategic change, along with counterparts to the successes, who had the same position as they in a different administration.

This paper uses the term "strategy" as it is used in Moore (1995) to include both a set of goals (vision) for where an executive wishes to take an organization, and a plan for how to achieve those goals. ${ }^{1}$ Such a plan involves both successfully receiving authorization and funds from the organization's external political environment, and improving internal operating capacity inside the organization.

The shorthand "success" will be used throughout this paper, but actually we refer to a certain kind of success - successful execution of a strong vision requiring significant organizational change. Most of the literature to be discussed in the hypotheses section below discusses relationships between use of various managerial techniques and general organizational success, not specifically success in executing strategic change. We return

We would like to thank Dave Lewis, Greg Dorchak, and David Martinez for help gathering the statistical data (such as leader tenure and percentage of political employees) presented here. We would also like to thank Debra Decker, Emily Rae, and a number of other consultants at Booz Allen Hamilton for assistance, and Booz Allen Hamilton for financial support of this research.

1 This is somewhat different from the everyday-language use of the term, which typically involves only the plan one has to achieve one's goals rather than the selection of goals as well, as in the phrase, "What's your strategy for persuading the boss to give you a raise?” 
at the end of this paper to the question of the extent to which techniques promoting success executing an ambitious vision and significant change are likely to be applicable to stewardship of a relatively unchanging enterprise.

This study is based on a small number of cases, with significant information gathered about each, mostly through interviews with agency leaders. Methodologically, however, we seek to avoid the pitfalls of so-called "best practices" research that draws conclusions based only on successful cases, creating the problem of selection on the dependent variable (Lynn 1996). If one chooses only successes and finds they did A, B, and $\mathrm{C}$, one really cannot conclude from this that A, B, and C caused success, because others (about which one has no information) may have done A, B, and C as well. Central to our research design, therefore, is creation of a control group alongside the successful executives, so we can compare behaviors of successes with those of others.

\section{HYPOTHESES}

\section{$\underline{\text { Strategy Formulation }}$}

Strategy formulation may occur using a strategic planning process - here loosely defined as an effort to develop, or clarify, organizational goals, and to prepare a plan of activities to be undertaken to realize those goals, in a comprehensive (sometimes called “synoptic”), prospective, and formalized fashion (Ansoff, 1965; Mintzberg, 1994; Bryson, 1995). Strategic planning is comprehensive in the manner of normative decision theory (Keeney and Raiffa, 1976; Stokey and Zeckhauser, 1978: Ch. 12), where goals are laid out, information gathered on alternatives and consequences (often from some sort of environmental assessment) and then activities chosen expected to maximize attainment of one's goals. The process is prospective in that strategy formulation lays out in advance both goals and activities; execution follows. 
A closer look at this literature shows that different authors emphasize different features of a strategic planning process. Some (e.g. Forbes 2007) emphasize a comprehensive environmental assessment - such as a SWOT analysis (strengths/weaknesses/opportunities/threats) that gives an organization more information about alternative activities and their consequences, which is then used for prospective choices about goals, or about broad kinds of activities in support of those goals. By contrast, Behn (1988) emphasizes, in discussing strategic planning, advance planning about choice of specific activities to reach goals.

Supporters of strategic planning argue it is associated with greater organizational success. The argument is the same as a general one for rationality. Planning, Bryson states, will improve decisionmaking and, hence, performance. Priorities identified in strategic plans encourage an organization to focus on what is most important. Fernandez and Rainey’s review (2006) of the literature on organizational change identifies transforming "the new idea or vision...into a course of action..., with goals and a plan for achieving it” as one key determinant of success.

However, others have argued that strategic planning is neither normatively nor descriptively associated with successful goal attainment. In a public-sector context, Lindblom’s classic critique (1959; see also Wildavsky, 1974; Quinn, 1980) argued that rather than trying to make decisions about either goals or activities in a comprehensive fashion, people should “muddle through" - start with current goals and approaches as a baseline and consider only limited, incremental alternatives, seeing if the alternative appears better. Behn argues that managers should have a clear idea of goals they seek (though he doesn’t really discuss whether a planning process produced goal selection), but need not - indeed, should not - have an advance plan for how to achieve the goals. A 
good manager (p. 645) "knows where is trying to go but is not sure how to get there." Instead, the manager "gropes along," trying different ways of achieving the goal.

One meta-analysis of studies on the relationship between use of strategic planning - here meant in the sense of comprehensive environmental assessment and careful goal selection - and financial performance of firms (Boyd 1991) found a positive relationship, though the underlying studies, almost all cross-sectional, are marred by endogeneity issues. Two studies using public-sector innovations that tested whether successful innovations had included advance planning of activities to be undertaken to realize the innovation's goal reached different results. Golden (1990) concluded that the time between idea development and first implementation of Ford Foundation award-winning innovations averaged about a year, suggesting to her that little implementation planning had taken place and that program methods had changed considerably during implementation. However, Borins’ (1998) categorization of a larger group of winners showed different findings. 59\% of innovations, once the decision to proceed was made, were preceded by a “comprehensive plan or analysis,” while only 30\% "groped along.” H1a: Successful agency heads be more likely than others to engage in a strategic planning process for strategy formulation. H1b: The planning processes of successful agency heads emphasize environmental assessment and goal selection. H1c: The planning processes of successful agency heads include development of implementation plans of activities to be undertaken in pursuit of the leader's goals. The strategy literature (e.g. Porter 1996) often argues that one purpose of a strategy is to help managers focus on a small number of priorities, rather than diluting attention across a large number of goals. As Porter writes (p. 77), "Strategy renders 
choices about what not to do as important as choices about what to do. ...(S)trategy requires constant discipline.” The idea is that one is more likely to be successful at whatever one does if one concentrates effort. Operationally, this would be expected to translate into a small number of important goals.

H2: Successful agency heads have a smaller number of goals than other leaders.

Research on organization strategy (e.g. Powell 1992; Floyd and Lane 2000; Kaplan and Norton 2006) frequently emphasizes a need for creating “alignment” among elements of a strategy, so internal capacity matches overall organizational goals. If the various elements of a strategy are in alignment, it is argued that the strategy stands a greater chance of success; Powell (1992) finds empirical support for this in a sample of business firms. Applied here, creating alignment would mean a leader made other changes to the organization that were consistent with the leader's goals. Examples might include adjusting budgets, employee job descriptions, or types of employees recruited.

\section{H3: Successful agency heads pay significant attention to creating alignment between} their goals and their agency’s internal capacity, more than other leaders.

\section{Engaging the Political Environment}

Perhaps the most-prominent argument for the view that successful strategy execution requires significant attention to the organization's political environment - the legislature, political superiors in the executive branch, organized groups, and the media appears in Moore (1995; see also Heymann 1987). Herman and Heimovics (1994) found that successful nonprofit executives were considerably more likely to use a "political frame” in thinking about their jobs - assuming conflict in the political environment and the need to build alliances to gain support - than the comparison executives they studied. 
Moore also writes (p. 76) that his view changes the leader's job from effectively delivering "current tasks" to one of "improvising the transition from current to future performance.” Engaging the political environment is particularly important for change efforts because these require new political authorization more than exercising stewardship over unchanging goals and means.

H4: Successful agency heads pay significant attention to engaging their external political environment, more than other leaders. Improving Internal Operating Capacity

Some observers have suggested that agencies are often not managed successfully because leaders attend insufficiently to creation of internal operating capacity. Cohen (1998: 475, 378, emphasis in original) states:

Many appointees are captivated by the glamour of their positions and ignore the fundamentals. They lavish their attention on travel opportunities, public appearances and speeches, press interviews, top-level policy meetings, and White House contacts, but they have little patience for the critical spade work that makes programs and organizations function effectively. They devote little or no time to working out key regulatory provisions, making budget allocations, building and nurturing the organization, determining critical personnel assignments, or translating policy concepts into operational reality. ... $\{W]$ hat's the harm of letting political appointees play the amateur government game? Isn't it a small price to pay? It is not such a small price, and it does a lot of harm.”

This has also been a common theme among "good government” practitioners - for example, the Partnership for Public Service (2008: 1) argues:

Most of government's management challenges...stem from a tendency of our federal leaders to emphasize policy at the expense of operational issues. The focus on policy is understandable. It is also a recipe for failure. ...

There are of course many behaviors a leader might undertake to create internal operating capacity. We focus on several here, although not as exclusive examples, that 
have been discussed significantly in the literature, particularly in the context of elements of capacity that are particularly relevant when leaders seek strategic change.

One technique recommended both as a way to promote successful change, and also to improve general performance is for management to involve employees through a participatory or collaborative management style (McGregor, 1960; Likert, 1961; but see Vroom and Jago, 1988; Yukl, 2001: 212-16 for suggestions this effect is situationally contingent). Growing out of Lewin's experiments during World War II on individual change (1947; 1958), this approach was first applied in the workplace in a field experiment (Coch and French 1948) involving a change effort.

H5: Successful agency heads use a collaborative, participatory management style, more than other leaders.

Between the 1930's and the 1950's (in documents such as the Brownlow Commission report of 1937 or the various Hoover Commission studies) reformers frequently proposed reorganizing government agencies (Fesler 1987). Reformers sought two main goals - to save money by reducing “duplication” and “overlap” among activities, and to improve hierarchical control and accountability by placing subordinates in clearer chains of commands to superiors (Thomas 1993). In the 1970's and 1980’s, by contrast, a conventional wisdom emerged among scholars studying organizations that reorganizations were generally worthless enterprises consuming significant energy while accomplishing little of value. Wilson (1989: 264; see also Seidman, 1970) observed that “presidents have taken to reorganizations the way overweight people take to fad diets and with about the same results.” March and Olsen (1983: 282) noted that “(t)he history of administrative reorganization...is a history of rhetoric,” continuing (p. 284) that “(n)either presidents nor congresses succeed often in major reorganization projects. What 
is proposed is regularly defeated or abandoned.” In the wake of September 11, there grew a new interest in reorganization as a technique to improve communication across stovepipes (Kelman 2006). Nonetheless, skepticism remains about the benefits of reorganization as a tool for organizational improvement.

Interestingly, the literature on change or transformation specifically does not appear to address reorganization as a technique specifically for change efforts, perhaps out of a view that it may distract leaders from spending time on change-promoting techniques seen as more beneficial in relation to their costs.

H6: Reorganization will not be an important technique used by successful agency heads, compared with other leaders.

Classic organization theory (e.g. Gulick and Urwick, editors, 1937; see also Behn, 2001: Ch. 1, 3) emphasizes clear hierarchical chains of commands, with undivided responsibility established for each element of an organization's production, and clear accountability for performance by each responsible individual or unit. Senior executives are responsible both for dividing the work, for receiving performance reports from those with responsibility for each given area, and for rewarding or punishing subordinates based on performance. Some (e.g. Hammer and Stanton, 1995; Kotter, 1996) argue that accountability systems are particularly important when executing change, since one can expect resistance, and therefore management must be vigilant about accountability. H7: Successful agency heads establish clear responsibility and accountability systems, more than other leaders.

In recent years, increasing attention has been paid to performance measurement as a tool to improve organizational performance (Hatry 1999; Behn 2003; Moynihan, 2008; Kelman and Friedman 2009), although there is an undertone of skepticism in the 
literature about its pitfalls (e.g. Bevan and Hood 2006; Radin 2006; McLean, Haubrich, and Gutierrez-Romero 2007). Performance measurement can improve performance by focusing organizational members on goals the measures embody, increase motivation to achieve goals, and facilitate learning through feedback and benchmarking.

Most attention regarding performance measurement has discussed its role in improving general performance (e.g. Rainey and Steinbauer, 1999), but it has also been suggested (e.g. Kaplan 2001: Ch. 1, 12) that if leaders seek to change the organization’s goals, one way to encourage this is to change measures to ones reflecting the new goals. H8: Successful agency heads use performance measures, more than other leaders.

A growing literature has developed in recent years (Perry and Wise 1990; Horton 2008; Perry and Hondeghem 2008a; Perry and Hondeghem 2008b) on “public service motivation,” defined (Perry and Hondeghem 2008a: 3-4) as involving motives for behavior "that are largely... altruistic and are grounded in public institutions.” Especially given the relative absence of extrinsic incentives available in government, public service motivation may be seen as one driver of good performance. There is empirical evidence (Brewer 2008), albeit limited, relating higher public service motivation to improved individual performance.

Discussions of differences between “management” and “leadership” (e.g. Kotter, 1990), associating “leadership” with change, argue that appealing to an attractive vision in a public-sector context, public service motivation - is an important leadership technique, so important especially in a context of change. There is also some discussion in the literature (Bardach, 1998; Kelman, 2005) of the role of public service motivation as a tool leaders can use to execute organizational change successfully. 
H9: Successful agency heads pay significant attention to cultivating public service motivation among employees, more than other leaders.

We will look in our data for information about use of these specific techniques for improving internal operating capacity, as well as any other such techniques that appear in the data. We suggest the following overall hypothesis:

H10: Successful agency heads pay significant attention to improving internal operating capacity, more than other leaders.

Relative Attention to Engaging the Political Environment and Improving Capacity

Moore regards the idea that successful engagement of the political environment is crucial for strategy success as perhaps his key intellectual contribution: he contrasts (probably unfairly; see Kelman, 2008) this conception with the one he argues was traditionally prevalent in public administration scholarship, which he sees as emphasizing management of internal operating capacity so as simply efficiently to deliver services whose content is defined by the political system and not influenced by the leader.

By contrast, accounts as early as Bernstein (1958: 30-33) reported that some executives themselves complain that the time they feel they must spend engaging the political environment detracts from their ability effectively to manage their organizations; “as a business executive,” Bernstein quoted one agency head, “I would never have dreamed of spending as much as one third of my time with my board of directors." Blumenthal (1983: 25-26), reflecting on his experience as a business executive turned Treasury Secretary, reported:

(A)s in any organization, you have to decide where to put your energies. You learn very quickly that you do not go down in history as a good or a bad Secretary in terms of how well you ran the place, whether you're a good administrator or not. You're perceived to be a good Secretary in terms of whether the policies for which you are responsible are adjudged 
successful or not. ... But that's not true in a company. In a company, it's how well you run the place.

These approaches suggest two hypotheses, only one of which can be true:

H11a: Successful agency heads prioritize engaging their external political environment over improving internal operating capacity, more than other leaders.

H11b: Successful agency heads prioritize improving internal operating capacity over engaging their political environment, more than other leaders. $\underline{\text { Agency Politicization and Expertise }}$

Although there are only 3000+ political appointees in a civilian federal workforce $^{2}$ of 1.8 million, there are more political appointees in the U.S. compared to most other democracies. This has been defended (e.g. Nathan 1983; Moe 1985; Muranto 2005) as a way to bring democratic responsiveness, along with fresh ideas, to government. It has also been criticized (e.g. Light 1995) for distancing expert civil servants from participation in decision making through excessive "layering” between careerists and appointees, and for demoralizing civil servants and hence reducing their diligence. More broadly, reliance on political appointees may downgrade the value given to substantive expertise in managing an agency.

Two recent empirical studies (Gilmour and Lewis 2006; Lewis 2008), using different methodologies, both concluded a lower percentage of political appointees was associated with higher agency performance. ${ }^{3}$ However, no empirical studies examine whether this finding applies to success at executing a strategy involving significant

\footnotetext{
2 Excluding the U.S. Postal Service

3 There might well, of course, be a tradeoff between responsiveness and competent performance (Miller 2005).
} 
change. ${ }^{4}$ If the argument for political appointments based on responsiveness and fresh ideas is correct, one might argue that fewer political appointees might be good for overall performance, but make change more difficult.

H12: Successful agency heads tend to come from agencies with relatively more political appointees as a percentage of agency employees, compared to the average agency. Length of Tenure

Agency heads in government tend to serve in their positions for a shorter time than do corporate CEO’s. Although average tenure of CEO’s is declining, it still averages seven years (Kaplan and Minton 2006). A recent study (Dull and Roberts 2008) of Senate-confirmed agency appointees found that on average during the first Bush and Clinton administrations, cabinet secretaries served 3.3 years, and Senate-confirmed appointees one level below the cabinet served on average 2.5 years.

One study (Jarymiszynx et al 1986) found a positive relationship between length of tenure as CEO and firm performance. Later studies (e.g. Kesner and Sabora 1994; see also Rainey and Steinbauer, 1999, in a public-sector context) have often found a curvilinear relationship, where organizational performance first rises with tenure, but later falls as the organization becomes too set in its ways, though the inflection point is far longer than typical agency heads serve. Long tenure increases the substantive expertise of a leader, which may aid performance. It may be especially helpful for leaders trying to execute significant strategic change, following Kelman’s argument (2005: Ch. 7-8) that there are positive feedback effects promoting successful change that occur with passage of time and persistence in a change effort.

\footnotetext{
${ }^{4}$ However, Borins (1998) did find that, for one-off innovations selected as semi-finalists in the Ford Foundation/Kennedy School awards program, almost half originated with career civil servants, more than twice as many as originated with the agency head, a finding that does not support the view associating innovation with political appointees.
} 
H13: Successful agency heads serve longer on average than other leaders.

\section{Techniques for Increasing Employee Acceptance of Change Efforts}

A common proposition in pop-management literature on change (e.g. Kotter 1996; Hammer and Stanton 1995) is that successful change occurs only in response to crisis. Since change is painful, employees must understand there is no alternative. As often put in consultant slideshows, getting people to accept change requires a "burning platform."” Such arguments receive a more general formulation in Cyert and March's theory of problemistic search (1963: 120-22) - absent problems, little motivation to change exists. The effectiveness of this technique, when used, in promoting successful change, however, is controversial (Kelman 2006). Therefore it is important to ask not only how commonly this technique is used by successful change managers but also whether successes use the technique more often (or perhaps less so) than failures.

In addition to using a "burning platform," two other, similar, ideas appearing in the change-management literature for gaining employee acceptance for change are that change leaders should seek to generate "quick" (Kotter 1996) or "small” (Weick 1984) wins early in the process. These seek to generate momentum behind change, to turn “neutrals into supporters, reluctant supporters into active helpers.” (Kotter 1996: 123) H14: Successful agency heads use techniques such as the "burning platform" or quick wins as methods to initiate change and persuade skeptical organization members to join a change effort, more than other leaders, and compared with those who seek major change but are unsuccessful in achieving it.

\section{DATA AND METHODS}

5 This is a reference to what it takes to rouse drilling workers on oil rigs from complacency. 
To choose executives whose behavior would be studied, nominations were solicited from two groups of independent experts: (1) fellows of the National Academy of Public Administration, a congressionally chartered honorary association designed to be like the National Academy of Science, but for distinguished scholars and practitioners studying or working in government $(\mathrm{N}=410)$ and (2) principals of the Council for Excellence in Government, a private non-profit organization open to people who have previously served in senior federal government positions but are not currently serving, most currently in academia/think tanks or in business $(\mathrm{N}=450)$. Authorization to contact members, along with email lists, were received from each organization.

These experts received the following email, signed by the lead author:

I am writing to you as a colleague and [NAPA fellow/principal of the Council for Excellence in Government] to request your help in guiding a research project I am starting. The purpose of the research is to study what it takes to get an overall organizational strategy implemented in the US federal public sector.

I ask you to think about leaders (at the subcabinet or perhaps cabinet level) during the last 15 years 1 ) with a clear, ambitious vision of what they wanted to accomplish during their tenure at their agency and 2) where implementing the vision required some significant changes in the agency's traditional behavior. Please limit your nominations to executives and strategies that have been or were pursued long enough to give it a chance to succeed or run into problems

Please nominate up to four executives and associated strategies - up to two where, in your view, the executives were relatively successful in implementing the strategy, and up to two where, in your view, the executives ran into significant difficulties.

The reasons for relative success or for problems may have been beyond the executives' control - that is something I want to examine in this research. Also, it goes without saying that you may personally like or dislike the executive's vision and the strategy - but you should nominate people based on the criteria above, not on whether you personally find their vision sympathetic or less-sympathetic. 
Two follow-up emails were sent to non-respondents. In all, 111 responses were received, for a response rate of 13\%. Responses generated a total of 93 individuals nominated as successes or failures. To be a potential candidate for inclusion in the research, we required a person to have received at least three nominations. ${ }^{6}$

This procedure generated seven successes. The top-ranking individual received 15 nominations (all as a success), a second received 14 (12 as a success, two as mixed), and two others received eight nominations each (all as successes). ${ }^{7}$ Nominations were heavily skewed towards successes rather than as people experiencing significant difficulties ("failure" for short, though this is not how the nomination request was phrased). One person received 11 nominations, five as having experienced significant difficulties, three as mixed (and three as a success); however, this person declined to participate in the research. $^{8}$ Another received three nominations, one as a failure and two as mixed. One received one nomination, as a failure. ${ }^{9}$ In addition, judgments on two people were on the borderline. One received five nominations, one as a success, two as mixed, two as a failure; another, one nomination each as a success, a failure, and mixed. As a robustness check of the nominations (and also to make classification judgments on the two borderline cases), we asked a group of insiders knowledgeable specifically about a nominee's performance - when available, people with similar

\footnotetext{
6 Some exceptions are discussed below.

7 One person received four nominations as a success, but had died before the research was conducted. . Another person was included in the group of successes having received only two nominations, both as a success, to achieve better balance between Clinton and Bush appointees.

8 One person received four nominations, all as a failure, but the judgment was made that this was due to a simple perception of the individual's poor performance on the job and that the individual had not attempted to execute any major strategic vision. Another person received two nominations, one as a failure and one as mixed, but when the research was conducted, the person was serving as an elected official, so the judgment was made he was very unlikely to agree to participate.

${ }_{9}$ We included this individual because of the small number of failure nominations.
} 
positions for each nominee ${ }^{10}$ - to rate the nominee's success, on a 1-10 scale, in achieving his or her goals. Results of this second process closely mirrored initial nominations. Those with many nominations as successes received high ratings (averaging from 8.4 to $9.5^{11}$ ) from the insiders. The two nominated as failures, by contrast, received ratings of 4.6 and 4.1. The two in the middle received ratings in-between - one an average of 7.6, the other 5.9. The decision was made to classify the first as a success, the second as a failure, since the average insiders' score for the first was much closer to those for success nominees than to failures, while for the second, the average was closer to the failures. ${ }^{12}$ This gave us eight successes and three failures participating in the research. Virtually all were sub-cabinet agency heads, except for one failure who was a cabinet secretary and two successes who ran independent agencies.

Since so few leaders were classified as failures, an additional source of comparisons to the successes was added. These were the counterparts to the successes those in the same positions, appointed at the same time in the lifecycle of an administration, in the administration other than the one of the success. So if the success was Bush’s first appointee, the counterpart would be Clinton’s first appointee to the position. The idea was to control for as much as possible, to make comparisons as free from noise as possible. ${ }^{13}$ As can be seen, the criterion for selecting the counterparts was

10 This included various senior managers (the organization's deputy plus several career managers), along with outsiders (such as congressional, White House, and OMB staff who dealt with the individual). 11 One individual with three nominations as a success had a somewhat lower average rating of 7.2. 12 Additionally, the 5.9 rating is too high. No ratings were obtained from external sources for this nominee; and therefore the rating reflects only internal sources. For every other nominee, for whom ratings from external sources were obtained, the average rating of the external sources was lower than for internal sources. Furthermore, the borderline nominee included as a success received a slightly higher average score from the insiders than did one other success nominee (7.5 vs. 7.2).

13 It was felt that position in an administration's lifecycle should be controlled for because first appointees might bring the energy and freshness of a new administration. It should be noted that one of the successful agency heads had been Clinton's second appointee, but the counterpart chosen was Bush's first appointee, because at the time of the interviews, Bush's second appointee to that position had just started his job. One 
a negative one: they were not nominated through our procedure as people who had tried to execute a strong, transformational vision. ${ }^{14}$ Some, however, may have been successful by other criteria; we do not address that question. One counterpart also refused to participate in the research. Thus, three failures and six counterparts constitute our control group. ${ }^{15}$ (Two failures came from one agency.)

Data for this study come from the following sources:

(1) Our major data source was an interview, either in person or over the phone, with each respondent, generally conducted by both authors. Each interview began with a general question where the respondent was asked to list his major goals and to discuss his plan for how to achieve them. Respondents were then encouraged to walk through what they did to achieve their goals, with very little direction from the interviewers, for as long as they wished. We also asked other questions, such as about the respondent's time allocation. Interviewees were promised anonymity as individuals and for their agencies. ${ }^{16}$

counterpart had received a single nomination as a failure (none as a success or mixed); however, his average knowledgeable insider rating was 7.0, which was moderately high, so we retained him as a counterpart. One counterpart had received one nomination as a success, not enough to qualify as a success based on our criteria, but because of this nomination we felt it was not appropriate to classify him as a counterpart, so he was left out. Finally, one of the successes was technically his administration's second appointee, because his predecessor was allowed to stay on his job about 18 months into the new administration. However, because the administration's intention was eventually to nominate a new person, we felt that in reality the nominee should be regarded as the first appointee. The designated counterpart (other administration's first appointee) declined to participate in the research, so we used the other administration's second appointee as the counterpart instead.

14 This procedure is similar to that used in Herman and Heimovics' (1994) study of executive leadership in nonprofit organizations. It may be noted that one counterpart had received a single nomination as a failure from the NAPA/CEG process. However, the person's average score from the knowledgeable insiders was 7.0, closer to the average score of successful nominees than failure nominees, so the person was retained in the counterpart category.

15 One of the counterparts had received one nomination from our process, as a failure. We considered this person for inclusion as a failure, given that we had included another person as a failure with only one nomination, as a failure. However, that individual had an average insiders rating of 4.6, while the individual we classify as a counterpart had an average rating of 7.5, closer to (though generally lower than) successes in our group.

${ }^{16}$ Further to anonymize respondents, all respondents will be referred to as "he," regardless of gender. Also, the phrase "agency head" will be used, although one of the respondents was a cabinet secretary. 
(2) Individuals knowledgeable about each success or failure (this was not done for the counterparts) were interviewed to gain additional background information.

(3) Various publicly available information was gathered on successes and controls, as well as their agencies. This included how long they served in their positions and the percentage of political appointees in the agency. ${ }^{17}$

(4) Stephen Barr, a Washington Post reporter who during the Clinton and Bush administrations was the paper's senior correspondent following the executive branch in general, first from the newspaper's "Federal Page" and then as author of the daily column "Federal Diary," was asked to rate on a 1-10 scale (blind to the reasons for their inclusion in the group) the media skills of each executive examined. ${ }^{18}$

All interviews were transcribed and entered into ATLAS.ti for qualitative analysis. The authors jointly developed coding categories for various techniques executives might have used, mostly based on published literature (including hypotheses discussed above), though sometimes based on what we had heard during interviews (Miles and Huberman, 1994). Transcripts were coded for mention of the technique in the part of the interview where the respondent was asked to present a spontaneous account of his activities. The senior author did the coding, though the two authors independently coded one interview before other coding began, as a consistency check. Coding, because it involved mention or non-mention of a technique, was quite straightforward.

The responses successes gave to the question asking them to list goals showed some sought changed goals - usually adding a new mission - while others sought

\footnotetext{
${ }^{17}$ With the publicly available information, we include in our group the two individuals who refused to be interviewed, plus the three not included in our group despite nominations (see footnotes 5 and 6 above), excluding the person we judged had been nominated as a failure because of perceived general poor performance. When we do this, we will refer to the data we present as being for the "broader group." 18 The specific question was: "How effective was this executive in getting across his/her messages when he/she interacted with you?”
} 
dramatic performance improvements achieving existing goals. Some sought both. Our subjective judgment is that goals varied in how ambitious or difficult-to-achieve they were, though they were noticeably more ambitious than those of the counterparts.

Our basic measure in this paper will be the number of spontaneous mentions of a technique by the successes and controls. The idea is that these mentions reflect approaches most-central to the respondent. The method is similar to one used in organizational behavior research involving corporate CEO’s (e.g. Abrahamson and Park, 1994; Wade, Porac, and Pollack, 1997; Kaplan, 2008) that looks at mentions of issues in company annual reports.

We will present two sorts of comparisons, between:

(1) the extent to which successes and controls used a given technique, to see which ones successes undertook more commonly than controls;

(2) the extent to which successes, compared to each other, undertook a given technique compared to other techniques, to see which techniques were most common among successes.

(These two comparisons won't necessarily yield the same result: if three successes used some technique and only one control did, the technique is more common among successes than controls, but if eight successes used a second technique, the second is more common among successes than the first.)

Since there is inevitably noise in respondent mentions of techniques - i.e. a spontaneous discussion in an interview does not necessarily fully reflect the mostimportant parts of the respondent's repertoire - any results showing differences between successes and controls, despite such noise, should be seen as conservative. 
A second complication is that by looking only at mentions, we ignore variations in how leaders used a technique - leaders pay attention to performance measures, or exhibit a collaborative/participatory style, in many different ways, and with different degrees of skill. This is similar to a problem identified in evaluation research - that using exposure to a broadly defined "treatment" such as participation in Head Start to examine its relationship with an outcome masks enormous differences in the actual content of Head Start programs (Light, Singer, and Willett, 1990: 96-97). However, here as well this problem introduces noise - we cannot distinguish based on mere mentions whether a technique was used well, and skillful use is presumably more related to success. This again biases relationships towards zero and means any results are conservative, and would be stronger if we had a large enough group, and enough information, to examine interaction effects based on contingent ways of using a technique. ${ }^{19}$

The small numbers make it unlikely any statistical tests would yield significant results (although, in informal testing, actually some results were significant at the .1 or .05 levels). We present only frequency distributions and not significance tests for differences between means for the two groups. Our groups represent (almost) ${ }^{20}$ the universe of those meeting our selection criteria, not a sample; therefore statistical tests are inappropriate. $^{21}$ One could argue that for our results to have external validity, they must be argued to represent a larger group from other than these two administrations, so in this

\footnotetext{
19 The same applies to the observation about the dependent variable, namely that certain techniques might work in situations where a leader's strategy involved changing goals versus dramatically improving performance on existing goals, or depending on how hard-to-achieve the goals were or how much internal opposition there was inside the agency to the goals.

20 One person refused to participate in the research, and two others were excluded for other reasons (see footnote 8 above).

${ }^{21}$ We are grateful for discussions with the senior author's colleague ANONYMIZED on this issue.
} 
sense our groups are samples of a larger universe. However, they are not random samples of that universe, again making statistical tests inappropriate.

\section{RESULTS}

Table One compares use of techniques by successes and controls, comparing relative use of the techniques, in descending order of the ratio of their use. Table Two presents a list of the most-frequently cited techniques the successes used, in descending order, presenting all those techniques successes mentioned at least twice. Together, these tables allow us to differentiate between successes and controls regarding techniques used.

--- INSERT TABLE 1 AND TABLE 2 ABOUT HERE --- 
$\underline{\text { Strategy Formulation }}$

There was a dramatic difference between successes and controls in the extent they used formal strategic planning to help establish goals. Six of eight successes, compared with only one of nine in controls (none of three failures), did so. H1a is supported.

Most of those discussing a formal planning process presented using it to help establish goals. Hypothesis $1 \mathrm{~b}$ is supported. One respondent stated:

I mean you've got to have a strategic plan. If you don't have a strategic plan all you can do is pray. You need a plan to figure to out what's your mission, what's your vision, what are your goals, what are your objectives, how to measure success. You know you need to have that in order to guide the organization, and to help maximize value and mitigate risk. So we developed a plan.

.... One of the things we did in the first strategic plan was that we had certain themes. They were trends - demographics, fiscal, rapidly evolving technology, increased globalization. They were strategic things that didn't have geo-political boundaries externally and they didn't have organizational boundaries internally. For the idea that you want to try to get people that when you're doing your work, whatever issue it is, think about these things, think about how they relate to what you're doing in order to try to provide more contextual sophistication.

Several respondents stated specifically they waited to finalize goals until after a planning process. One stated he regarded his initial activities on arriving at the agency as "shortterm stuff," adding that he told staff afterwards, "Now let's convert this more into a strategic plan as to what we want to do in terms of substantive changes.” Another noted:

[We] initiated an effort to try to understand where we were and where we were going. So the first phase of all of this was basically the input phase and really trying to get as much understanding and awareness of what our employees thought and what the people that we were supposed to be serving thought that we should prioritize and put at the front of our burner. We spent about a year fact-finding.

Only one control discussed having a strategic planning process, while another (one of the failures) specifically noted that "one of the things that we didn't have was a very concrete strategic plan about what we were going to do.” 
However, only two of the eight successes mentioned using planning to select operational or implementation activities. The evidence thus seems consistent with Behn's suggestions that successful executives do, or should, think about their goals in advance, but not so much about paths to reach them. H1c is not supported. One of the successes actually sounded like Behn: “There was an awful lot of, 'I have a general idea where I want to go but then you have to take advantage of the opportunities.”,

One unexpected finding ${ }^{22}$ was that on average the time between nomination and confirmation was longer for successes than for controls - the average wait for successes was 2.8 months, compared with 1.9 months for controls. ${ }^{23}$ (The association between a longer nomination-confirmation gap and success may be understated because a long gap suggests controversy over appointment, which would tend to make it harder to succeed.) This finding contradicts the conventional - and commonsensical - wisdom (e.g. Light 2008: Ch. 2-3) that confirmation delays compromise the ability of agency leaders to do a good job, by shortening their tenure and leaving agencies leaderless longer. The explanation for the counterintuitive result seems to be that nominees are able to use a long confirmation wait - during which they can learn about the agency’s problems, and get to know people in and around the agency, but may not actually make decisions - as an apprenticeship period to learn their job (without pressures of decision making), get to know relevant people, and think about strategy.

\footnotetext{
22 There had been no plan to look at this question until, during the interviews, a number of the successes spoke about their long nomination-confirmation gaps, and how they used these to prepare for their jobs, while one of the failures noted he was able (for a reason not mentioned here because it might compromise anonymity) to start working on the job immediately.

23 These figures come from public records (such as biographies or Wikipedia entries); in a few cases, it was impossible to obtain confirmation dates, so swearing-in dates (which follow closely on confirmation) were used instead. Each individual nomination-confirmation gap was rounded to the nearest month. The agency heads in two of the organizations were not subject to Senate confirmation, and they are not included in these calculations. These figures are for the broader group. Three in the broader control group were cabinet secretaries, who are generally confirmed more quickly than others; if these individuals are excluded, the average gap becomes 2.1 months, still shorter than for the successes.
} 
Four successes (compared with only two controls) mentioned using the period between nomination and confirmation to think about goals and gather information about their organization. Stated one:

I spent as much time as I could getting up to speed, learning. And I did that by reading. And there was a huge amount of work that had been done. There had been studies internally; we had studies galore. I was a little restricted because you couldn't talk to people outside the agency for the most part, but I could talk to a lot of people inside the agency. this is where in this particular case the lag before you get confirmed actually was helpful.

Another success also talked with outsiders:

I set out to do an assessment. I did a complete assessment of where [the agency] was. I talked with experts - you talk to people, it's amazing what they tell you. All you got to do is take some people to dinner or invite them to a room and chit chat, close the door and make it anonymous. And they open up.

On average, successes gave a somewhat smaller number of goals than controls 2.3 versus 3.0 (failures had an average of 3.7). ${ }^{24}$ This suggests the successes were somewhat more focused than controls. H2 is supported.

Few mentioned efforts to align various parts of the organization to their goals. Only two of eight successes (the same as the number of controls) reported seeking changes in relative budget allocations to align budgets with goals they had adopted. Only one success (no control) mentioned aligning job descriptions or recruitment to the new goals, or examining the organization’s business processes for alignment. None mentioned changing employee incentives or promotion paths. H3 is not supported.

\section{Engaging the Political Environment}

Overall, H4 is supported. Judged by the number of mentions, there were differences, but fairly modest ones, between mentions by successes and controls of

\footnotetext{
24 In addition, one of the eight respondents in controls stated he had no goals when starting.
} 
working proactively to persuade Congress to support their goals. Six of eight successes mentioned this, ${ }^{25}$ compared with four of nine controls (but two of three failures).

However, qualitative differences in what people said about Congress were larger. Most successes discussed their interactions extensively. One recounted that, as part of developing his initial goals, he spoke with 25 members of Congress.

When you have to make major change, if you don't have the support, in a democracy, in Congress and in the White House, you can't do it. I decided that that's where I wanted my support. ...Within two years of taking office, I touched every member of Congress. Every member, not just my committee. There are 535 members of Congress, and I saw 250 a year.

A second discussed how he sold change he sought to a skeptical committee member:

He's a good old boy from Wyoming. He's into law and order, so I went back taking a law and order approach. I went to his office and spent two hours, basically going over how I can't hold anybody accountable. .... So, we had a very good conversation, which I characterize as basically law and order conversation. He had some follow-up a few days later. Two weeks later, he removed his opposition. ...The whole strategy was repackaging it in a way he could understand it and relate to it, and convince them that he needed to rethink this view as well.

Only two of the four controls who discussed working proactively with Congress sounded like most of the successes. The other two mentioned this technique more perfunctorily than any successes did. And three of the five controls who did not mention dealing with Congress proactively did discuss Congress, but either in reactive or negative terms. The only statement about Congress one of them made was, "You know, one of the first lessons inside the Beltway is you need to heed what your oversight committee says.” Another counterpart referred to Congress twice, both negatively. Discussing with whom he spoke in setting goals, he stated, "Then of course you get the ever-present whether-

\footnotetext{
${ }^{25}$ The goals of one of the two successes who did not mention this technique mostly, though not exclusively, involved implementing a law Congress had past; one might therefore argue that it was unlikely that this person's goals called for proactive work to persuade Congress.
} 
you-like-it-or-not Congress that wants to tell you all about their view, you know whether you need it or not.” A third respondent stated:

You go to the hearings, and, you know, some of those things, it's like going to the dentist. ...It is non-stop, I mean with Congress, it is non-stop. That's the way you should be doing it, but it has the potential to divert you from your knitting. At home, you've got knitting that you've got to be doing, running and managing your organization. ... [But] you've got to do what you've got to do.

As for the White House/OMB, three of seven successes, ${ }^{26}$ compared with only one of nine controls (one of three failures), discussed working proactively to gain support there. One included Office of Management and Budget representatives on a committee to determine the agency’s future budgetary needs, hoping to use this to gain eventual support for his major goal, which required a large budget increase. He also placed employees in White House details. A second contacted White House staff to hear their ideas for goals he ought to pursue. A third noted that "what was incredibly important in making these changes was that the employees within [the agency] knew how close I was to the President. ...And they knew that the President supported these efforts.”

Dealing with the White House proactively to gain support was hardly mentioned by controls. ${ }^{27}$ Furthermore, one of the three failures expressed negative feelings about interactions with the White House:

There was a point in time where there was what I considered to be somewhat unnecessary engagement by the White House, where the President assigned a guy [to give us suggestions and advice]. ...We got a series of [White House staffers assigned to our agency], some of which we got imposed on us without much consultation or collaboration. ... You don't do anything in this town that's major without White House approval;

\footnotetext{
26 For one success, gaining White House support was not something this agency would ever have sought, given its mission and organization.

27 One might argue that, given limitations on White House staff time, it would be implausible to believe that the counterparts, most of whom had more modest agendas than the successes, could have gotten active White House support even if they had sought it.
} 
and sometimes you have to get the approval of people who may not have the depth of knowledge or the appreciation for why you want to effect the change, but that's just the way it is.

Two other external constituencies - interest groups and the media - featured, though only peripherally, in respondents' accounts, far more in those of the successes than controls. Five successes, but only one control, mentioned cultivating interest groups, but mentions were brief (except, actually, for the one counterpart mentioning this, who discussed at some length organizing business leaders to support gaining budget money for the agency’s expansion plans). One counterpart discussed being forced to deal with interest groups as a negative feature of his job. Cultivating the media was mentioned by three successes, again only briefly (by no controls). Finally, two successes (no controls) briefly discussed dealing with employee unions to gain support for their goals. ${ }^{28}$

Although only a modest number of successes mentioned the media, evaluation of leader media skills by the Washington Post reporter showed large differences. The mean score (broader group) for successes was 8.1, for controls 6.0 - for failures 5.8, counterparts 6.2. ${ }^{29}$ These differences are understated, because they do not include executives for whom the reporter could not provide a judgment, reflecting insufficient familiarity with their media interactions and thus suggesting poor media skills; the reporter was unable to rate only one of ten successful executives but four of 14 controls. $^{30}$

\footnotetext{
${ }^{28}$ Employee unions are not mainly an external constituency (although union locals in an agency are part of a national union organization); this behavior is classified as external because it involves the same political skills as dealing with traditional external constituencies.

${ }^{29}$ We discuss the question of the possible endogeneity of these results at the end of this paper.

30 Additionally, one of the counterparts refused to meet with the media, which would suggest poor media skills. However, Barr chose to rate this individual as "unable to judge" rather than giving him a low score. In the case of the counterpart where there was a difference between the person initially identified and finally interviewed (see footnote 10 above), Barr gave an "unable to judge” rating to both.
} 
More broadly, four of eight successes, compared with two of nine controls (none

of the failures) mentioned relationship-building and personal ties to gain support for their

goals. Two of those mentioned this primarily regarding external constituencies, the other

two more generally. Stated one, "Relationship building was fundamental to anything we

did.” Another of the successes discussed this issue at length:

It occurred to me that if I was to, if I look forward down the road to needing the support of A, B, C, D, and E, and the first time I ever met them was when I needed their support badly that was not a good thing. The middle of a crisis is a bad time exchange business cards.

If you have not gone to through the trouble of making those investments up front, when it comes crisis time or budget time or review time or whatever, if you can't look around the table at who[m]ever is assembled and know most of them and have exchanged coffee with them, played tennis with them, you're in trouble. I'm not a golfer. I'm not quite old enough for that yet. But I methodically went about the business of trying to play tennis with as many players as I could that knew to play tennis. ... When push comes to shove maybe the ball will tilt in your direction because you made that investment. ...

I took inventory of the members of the [congressional] committees. ...And I methodically went about getting on their calendar to meet them and then as was necessary, successively thereafter meeting them time and time again. You know, whether it was a social opportunity or a professional opportunity that brought us together. I built relationships with those people. ...

[We looked for] opportunities to take the member when he was on at home in his district to visit [one of our installations] in the district. ...But there was nothing like actually going to the scene of the crime so to speak to learn the lessons vividly [about what we needed so they would] become a supporter at the other end of the day. But that just didn't happen. It took a thought pattern. ... There are maybe five members of the Congress who [had served in our agency earlier in their career]. And I can tell you who they are and where they live and what they drink and what they breathe and whatever.

A third stated he visited 20-30 districts a year.

I had town hall meetings - come in the night before, spend the whole day with the members of Congress from that area, we'd go to schools, factories, radio, talk radio. And I got a real feel for the texture of what was important to them.

Improving Internal Operating Capacity 
(1) Seven of eight successes mentioned adopting a collaborative, participative management style as a technique to gain support for their agenda. This was the single most-mentioned technique the successes used. By comparison, four of nine in controls mentioned using this technique, so differences between the two groups were moderately large, although not as large as for some other techniques. Additionally, two of three failures reported using this technique, so, although the numbers are very small, it is harder to conclude that using this technique distinguishes those successful at achieving significant change from those trying but failing. Thus, H12 is partly supported. Perhaps use of this technique distinguishes successes from controls as something used to promote general performance improvement, but not, as in the Lewinian tradition, a way to initiate an attitude change process among employees.

Examples of statements on a collaborative style by the successes were:

I said we have some issues we've got to deal with, and I want to work these out together. Here's what the issues are, and in three days we're going to have a brainstorming session. People didn't know what a brainstorming session was. ... Very early on one of the things I found is that whenever the [head of the organization] said something, people just implemented it. What they weren't used to with me is that I'll talk about things and say, "Look, I got an idea here. Here's something I'm thinking about. You know we need to talk about it.”

I said [to my career chief of staff], "I want you to pick six people, six career employees that you know are very talented ,and I want you to head the team to work with us on the reorganization of the agency. Not politicals. ... Then we gave them the new organizational structure. We gave them the priorities and goals that we had established for the first year. And I said, “Here's what I want you to accomplish in these three days. I want you to divide up in teams. Half career, half political. I want you to look at the goals and priorities that we've come up with for the first year. You can add to or take away whichever you choose. I want you to come up with a new mission statement based on the new organization, and based on the priorities and goals. And I'm going to come back at the end of the three days and expect you have it accomplished....And what was amazing when I came back at the end of those three days was that the 
reorganization, and the priorities and goals, and the new mission statement were theirs. Not mine. They had bought into this. ... they had to be part of the change. The change would never have happened without them being part of it.

However, a number of controls (the first quote from a failure, the second from a counterpart) sounded similar:

We spent a day, had people brainstorm ideas, and I literally sat in the front of the room after the group reported back, "Yeah, let's do that," "No, we won't do that." But it was I think pretty classic, "I'm here to change things. I want your ideas. We're going to do that idea, let's run with it." ... The commitment I made is that we put a working group together, and they could rewrite [an important set of agency procedures], and that when they came up with it, I would implement it. And that was a really important initiative.

Well, I'm a consensus builder, I'm a facilitator. ...I wanted to build collaboration, consensus, and loyalty towards the departmental goals, not loyalty to self but loyalty toward the goals, through a more collaborative senior management process. So, specifically the [regional managers] comprised an executive leadership council, and I really saw that as a pivotal way to move the strategic imitative forward. If you will, building towards consensus management or participatory management.

(2) Six of eight successes (compared to three of nine controls) ${ }^{31}$ mentioned they had reorganized. This difference is even more dramatic because controls discussing reorganization did so far more perfunctorily than successes. H6 is supported.

In terms of reasons successes gave for reorganizing, none mentioned either saving money from eliminating duplication or establishing a clearer command structure. Five of six stated the major reason was to reduce stovepipes.

The [new] structure brought together parts of [the agency] that had been highly separated and segregated into a common operating platform where there would be opportunities for enhancing synergies by using the structure as well as the other good intentions and management practices.

\footnotetext{
31 One of three failures reorganized. However, some special features of two of the three failure cases (that cannot be specified without compromising anonymity) make it less likely these leaders would pursue reorganization, although actually one of those two did discuss doing so.
} 
The sixth discussed reorganization as a way "to get people’s attention to set the stage for the change function.”

Although six successes discussed reorganizing, three said they did so despite a bias against it:
All reorganizations basically are an indirect way of getting at something. I mean directly reorganizing doesn't do anything for a customer, right? ...In theory you can do anything without reorganizing if you wanted. It's just that it's a means to an end. People are very, very skeptical, and justly so, of reorganizations because by themselves they cost a lot, they're risky, and by themselves they don't change the experience. What they do is enable change.
My bias is to never reorganize. Because I don't think the structure is the determining step, nor can you solve leadership problems by restructuring. But I listened to the people who were working on this, and when the proposal came forward that our structure really wasn't going to support integrated effort, then we needed to really think through that.

(3) Only a modest number of respondents spoke about having a formal accountability system for individual managers with lead responsibility for goals. Three of eight successes mentioned this (two of nine controls). H7 is not supported.

Two of the eight successes noted that steps were taken to deal with nonperforming managers; no controls discussed this. One of the successes noted that "people left their jobs”; when the interviewer asked whether this was involuntarily, the respondent answered, “Involuntarily if they didn’t meet their metrics.” Another discussed accountability at some length Before coming to the organization, he stated,

There wasn't the proper level of accountability that went with responsibility, in my mind. And I wanted to assure that. ...In a ten minute period, I reassigned eight or nine of the top administration. Out of 20. I reassigned them. I didn't fire them, I reassigned them. 
In managing the changes he sought, the leader stated, "You need to have appropriate responsibility assigned.” He added that metrics “were measurable, and people had to perform. I expected performance.”

However, two counterparts discussed this issue as well. One failure stated:

We set up a matrix of goals, a timetable to meet the goals, identify individuals accountable, and a periodic review to see how far we got. ...I would meet with them once a week, talk about policy, general performance, problems we had to deal with during the week, and [my deputy] would meet with them once a week to talk about performance, talk about moving the matrix forward, talk about timetables and goals. ...Individual accountability and weekly meetings became part of the routine, the rhythm of the [organization].

A counterpart noted that he picked "point people from among the career staff at the agency who would handle each one of [my] initiatives. I would then put it on my schedule at least a weekly if not more frequent meeting with the person about that issue.”

(4) Six of eight successes mentioned using performance measures to move their agenda, compared with three of nine in controls (only one of three failures). H8 is supported. . Above this theme, two of the successes who raised this issue (along with the one failure who did so) also spoke about performance measurement as part of a change process in the organization. One stated he regarded changing the agency's metrics as a key long term element of his change effort. A second noted that "we are learning to use project management, support and feedback, and scorecarding, all ... that were not part of [the agency's traditional] approach to things." (The failure who discussed performance measurement noted that "the [previous] measurement system was heavily tilted towards process activity....as opposed to actually trying to say, " Let's [try a change] initiative, and let's measure the impact, and if it works, let's do more of that, or let's redesign it.") 
(5) One of the most common techniques the successes used (mentioned by five of eight) was to connect their agenda to public-service motivation among employees.

However, this behavior was mentioned just about equally frequently by controls (five of nine, including two of three failures). Appealing to employee public service motivation thus did not differentiate the groups. H9 is not supported.

Some successes that discussed this technique stated:

[You want to relate] what you're trying to accomplish with something that they can really believe in and want to be a part of. ...Y You know, it's easier to work hard when you know that that work is amounting to something and it's for a goal that you believe in. so we spent a good deal of time... hit[ting] on the major themes of what the agency's trying to do and how the different pieces of the agency all fit into that.

To energize and to stimulate and to inspire are good things for one as a leader to take on. And if you failed to do that, regardless of how brilliant your bureaucratic package might be it, you know, it's probably not going to get much traction. But if you have energized and inspired your people to the direction that you want to go, they will follow. You know, it's an extraordinary thing but it actually works.

And I told them, I said, “Look, I know change is difficult,” but I said, "Work with me on this. Let's build [this agency] to make it something that you can be proud of, that you can be proud of coming to work, that the American people can be proud of. ... At every opportunity, we would sit down, talk to people, and reinforce the difference this is going to make for them and their job and their career. But the most important thing is how we will want to help the American people when we needed to.

However, failures (first quote) and counterparts (second quote) didn’t sound so different:

Part of the key to this was capturing that sense of mission with initiatives. And the more results show that things were getting better, and that they had a chance to have an impact, the more support came along.

[Our employees] knew that that was very damaging to our agency, and to taxpayers and beneficiaries, that money was being wasted [due to a problem the agency had that was this leader was trying to deal with as a priority goal]. It undermines faith in government. It undermines faith in what they were they were to do. And they all were drawn in government for the right reason. So I was really gratified and honored to work with 
those career civil servants because they did every thing they could to make me successful in achieving that goal.

(6) A number of other techniques to create internal capacity, not among our hypotheses, were discussed. Five of eight successes (two of three failures, but no counterparts) discussed developing slogans related to their agenda. One stated that "the question always had to be, 'Are we providing equal and better value than the private sector?", 32 Another discussed searching for metaphors and "catch words" that would make his goals easier to understand and support. A third noted that a slogan came from staff working on the changes. "I think they felt they needed an identity. And they were trying to find a way to make a buzz.” Since developing slogans might not be necessary for counterparts with a less-ambitious agenda, and since two of three failures also used slogans, we are unsure whether use of slogans differentiates successes.

Working more generally to communicate the leader's agenda to employees was discussed by only three of eight successes, and actually by a larger number of controls (four, including two of three failures). The tone of comments was also similar. A success noted that when he started as agency head he "went over to [the organization], and I gave a speech, and I outlined exactly what I wanted.” Another noted:

Take for example the [annual address the head of the organization gives about the state of the organization]. Those were extraordinary opportunities to say what it is that you had to say. My belief in [our agency] as an extraordinary organization had to find itself way into the speeches. ... And they all had to be short enough that people would also actually still be awake. I worked very hard [preparing them] and probably had a dozen iterations of those speeches.

At the same time, one of the failures stated: "I think it was very important, for any organization that's going to effect substantial change, is to create as many means of

32 Most of the slogans cannot be presented here, because they would reveal agency identities. 
communication, information sharing interaction as possible. Website, newsletter, meetings.” A counterpart stated:

We needed to communicate and keep folks up-to-date on what's going on in throughout the organization. So they knew, so they understood why change was happening. The worst thing I think you can do is you do some change and the people in the trenches don't...understand the context in which things are happening. So the communication strategy that I came up with was let's communicate what we're doing, why we're doing it, what the timelines are, what the expectations are, what this means to the individual in [the organization], how you can contribute to the effort, and why it's important to the nation, and to him or her.

(6) We look at the mentions of the various techniques for creating internal capacity discussed above to see whether successes paid more attention to creating operating capacity than controls. They clearly did. H10 is supported. Relative Attention Paid to Engaging the Political Environment and Creating Internal Capacity

Four of five differentiators scoring high on both absolute number of mentions, and on the ratio between mentions by successes and by controls, involved creation of internal capacity. ${ }^{33}$ Additionally, respondents were asked how they divided their time between internal activities (time with staff in their own organization) and external ones (with outside constituencies, including government constituencies such as the White House). Both successes and controls reported spending a somewhat larger proportion of time externally than internally. There were only small differences between successes and controls, but successes did spend a somewhat larger proportion of time internally: on average 54\% externally, controls on average 59\% - and the three failures $73 \%$. Furthermore, outreach to two of four constituencies (White House/OMB and employee

\footnotetext{
33 Strategic planning, one of the four, can be seen as creation of an internal capacity that may, although it did not generally in the cases here, include outreach to external constituencies.
} 
unions) was mentioned relatively infrequently by successes as techniques to promote their goals; and while successes mentioned dealing proactively with Congress very often, more often (both quantitatively and qualitatively) than controls, differences were not as dramatic as for the five biggest differentiators. Dealing proactively with the media was mentioned relatively rarely, in contrast to the popular image that government leaders regard media relations as the most-important feature of the job. Finally, six of eight techniques successes mentioned most (five or more mentions) involved creation of internal capacity rather than dealing with the political environment. Taken together, these results are more consistent with $\mathrm{H} 11 \mathrm{~b}$ than with $\mathrm{H} 11 \mathrm{a}$.

\section{$\underline{\text { Politicization and Expertise }}$}

Table Three displays the percentage of political employees as a percentage of the total number of agency managers for the agencies of the successes (broader group), along with the average percentage for all civilian agencies. ${ }^{34}$ For all but two, the percentage was lower - indeed, dramatically lower, by factors of ten or even a hundred -- than for civilian agencies as a whole. ${ }^{35} \mathrm{H} 12$ is not supported. Instead, results are the opposite, consistent with those regarding general agency performance.

\section{--- INSERT TABLE 3 ABOUT HERE ---}

Most of these leaders, both successes and controls, had significant expertise in their agency's substantive area before taking their jobs. However, there were some differences between the two groups. $\underline{\text { All }}$ ten successes had significant background in their

\footnotetext{
34 Data was generously provided by David Lewis, and expands on material presented in Lewis (2008). His definitions for "managers" and "political appointees” are used. All our success cases were civilian agencies.

${ }^{35}$ For the (only) two failure agencies, percentages hovered close to the average for all civilian agencies $1.7 \%$ for one, close to $1 \%$ (actually, $0.9498 \%$ ) for the other; the government average is $1.5 \%$.
} 
substantive area. For controls, ten did but two (or three) didn't, and an additional person was classified as intermediate, having been a former elected official with some experience in the substantive area, but not a professional background in it. ${ }^{36}$

There is an additional dramatic finding. Leaders of half the successful agencies (broader group) were in positions with fixed terms, generally five years, rather than at the pleasure of political superiors, and thus in less-politicized agencies. This finding is especially dramatic given how rare fixed terms are in the federal government.

\section{$\underline{\text { Length of Tenure }}$}

Successes served in their positions on average 5.6 years, compared with an average of 2.6 years for all Senate-confirmed appointees in the Dull and Roberts (2008) study. ${ }^{37}$ (This still puts them below the length of service where performance starts to fall in studies showing a curvilinear relationship.) By contrast, the failures served on average 3.2 years, close to the average for all Senate-confirmed appointees. ${ }^{38}$ These results support H13. However, this could be partly or fully endogenous - individuals may have stayed longer because they were successful. However, counterparts ${ }^{39}$ served on average only 2.7 years, lower than the failures, a result not consistent with an endogeneity story. Additionally, fixed terms are a clearly exogenous source of lengthy tenure, and, as we have seen, successes dramatically came from agencies whose heads have fixed terms. ${ }^{40}$

\section{Techniques for Increasing Employee Acceptance of Change Efforts}

\footnotetext{
36 The broader group was used here. For one counterpart (see footnote 10 above), we ended up interviewing a different person from the one originally identified. If we use the person actually interviewed for the rest of the research as the counterpart, the number of non-experts in controls is two (plus the intermediate case); if the originally identified counterpart is used instead, the number is three.

37 These calculations are also based on publicly available data and include the broader group. If one excludes individuals serving fixed terms of office, average tenure for the successes was 5.8 years.

38 It may also be noted in this regard that fixed terms (discussed above) are also relatively long terms. Successful executives discussed in Doig and Hargrave (1990) served on average 14 years.

39 Excluding those serving fixed terms

${ }^{40}$ We are grateful to David Lewis for making this point to us.
} 
For the change initiation techniques "burning platform,” “quick wins,” and pilots, numbers of mentions by successes and failures was calculated; ${ }^{41}$ comparisons here are use of the techniques compared to each other, use compared to other managerial techniques, and use by successes versus failures. Use of none of these techniques was mentioned much, and their use was actually mentioned by failures proportionately more than by successes. H14 is not supported.

Only one of eight successes discussed using the "burning platform" the way the idea is classically discussed, i.e. as a method to overcome resistance to change in one's organization (and one of the three failures used the technique this way as well). When the government shut down in 1995, one respondent pointed to this as an example that no organization was sacred any longer, even an organization like the leader's own, which had a powerful political constituency. "Hey, look around, guys. The world has changed. It's very different. You cannot assume that what you took for granted yesterday is still true. ... Internally, that was useful for selling the idea that we really had to change.”42 Additionally, two respondents stated they announced a policy there would be no layoffs at their agency in the wake of changes being implemented, a policy passing up on one occasion to create a burning platform. Only one success discussed seeking quick wins. Summarizing the Results

\footnotetext{
41 It was not expected that counterparts would mention these techniques, nor was a comparison with counterparts considered appropriate, because they were not chosen based on any agenda for significant change. Not surprisingly, then, no counterparts mentioned using any of these techniques.

${ }_{42}$ In addition, three successes mentioned a realization on their own parts that their organization was faced by crisis (some actually used the expression "burning platform") as something that helped them recognize the necessity of major changes in how their organizations behaved, but made no reference to using this as an argument to persuade others within the organization. (For example: "The agency had been down sized $40 \%$ in the five years before I came for a variety of reasons. ... And it was exposed to another round of cuts. I received as part of my due diligence access to a [survey of stakeholders of the agency] that nobody else in this agency has ever seen. ....And basically it showed you know why [we] had been downsized. And it also demonstrated that it still was at risk. And so I was informed by that to try to help analyze... what I thought need to be done for us to mitigate the risk of there being another round of downsizing.")
} 
Five techniques scored high on both measures - mentioned by five or more successes, and also more than twice as often by successes as controls. These leading differentiators were: (1) strategic planning, (2) using performance measures, (3) reorganization, (4) proactively working with interest groups, and (5) using slogans. ${ }^{43}$ (As noted, however, discussions of working with interest groups were brief; and using slogans may not differentiate successes from failures, though numbers are very small.) By slightly more liberal tests, two additional techniques qualify: (1) a collaborative management style (just short of being twice as frequently mentioned by successes as controls, though, again, use of this technique may not distinguish successes from failures), (2) relationship building (four mentions by successes, and just-better than twice as frequently mentioned as by controls). Finally, working proactively with Congress was very-frequently mentioned by successes, and, while mentioned also quite frequently by controls (and especially failures), tended to be discussed with more gusto by successes.

Several hypotheses were not supported. One technique (appealing to employee public service motivation) was frequently used by successes, but just as frequently by controls. Others -communicating goals with employees, accountability systems, changes in budgets to reflect new goals - were mentioned only occasionally by successes, and about or more frequently by controls. These results illustrate the importance of having a comparison group, as opposed to "best practices” analysis examining only successes. Other hypotheses not supported included using techniques to align features of the agency’s internal capacity to the new strategy and using techniques to encourage

\footnotetext{
43 As noted, discussions of working with interest groups were brief, and reorganization and use of slogans may not differentiate successes from failures (though numbers are very small).
} 
employee support for change such as the "burning platform” or "quick wins"; these were seldom mentioned by successes and often mentioned as frequently by failures.

We may compare these results with techniques used by seven outstanding twentieth-century public executives portrayed in Doig and Hargrave (1990), in Table Four. $^{44}$ (Their volume has no controls.)

\section{--- INSERT TABLE FOUR ABOUT HERE ---}

Their results are quite similar. Most of these successful executives were reported to have significantly engaged their legislatures, significantly more than the number engaging the media or top political leadership. It is surprising how many developed slogans to describe what they were doing, like successes in this study. Three techniques collaborative/participatory management style, strategic planning, and (with less of a difference) appeal to employee public service motivation - were used considerably less often than by leaders studied here. This may reflect that many executives in Doig and Hargrove worked in early decades of the last century, before these became common management approaches or, in the latter case, before workforce changes that may make appeal to public service motivation more effective.

One important finding is that our very small group of failures - as distinguished from the entire control group -- seems to have used techniques specifically for managing

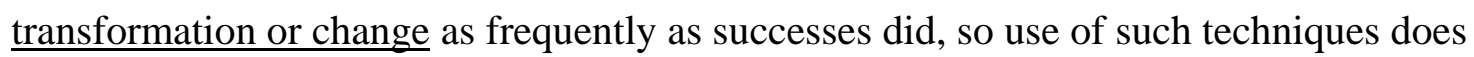
not differentiate successes from failures. The failures seem to have read the same change

\footnotetext{
44 This table is based on reading this volume with specific attention to techniques the authors discuss the executives as having used. The book itself presents no table like the one presented here.
} 
management literature as the successes, and used the same change management techniques as they did. Instead, what seems to differentiate failures from successes is that failures were less likely to use techniques associated with improving general organizational performance (performance measures, strategic planning, reorganization, few goals). They appear to have read the books on change management, but not on general management. Almost all techniques especially recommended for leading change either were not frequently used by successes (e.g. the "burning platform”); appear to differentiate successes from counterparts, but not from failures (e.g. a collaborative/participatory management style or use of slogans); or do not differentiate at all between successes and controls (e.g. appeals to public service motivation). Despite the argument that engaging the political environment is particularly important for successfully instituting change, failures actually spent a noticeably larger proportion of their time engaging the political environment than did successes. Finally, while it is sometimes argued that political appointees are helpful for achieving change but less so for producing good performance on stable goals, our results are that successes were likely to come from agencies less-politicized than average. These findings again show that it is helpful from a research perspective to go beyond a "best practices” approach. How Much Effort Did Respondents Put Into Their Jobs?

We asked respondents the length of their average workweek. There were not large differences between the two groups, although the small differences pointed towards controls having somewhat longer workweeks than successes. The mean workweek of successes was 66 hours, for failures 77 hours, and for counterparts 72 hours. The range for successes was 50 to 85 hours, for controls 60 to 90 (for failures, 70 to 85 ). For the six 
cases where data are available both for a success and a counterpart, in all the counterpart reported working the same number or longer hours than the success, none fewer. ${ }^{45}$

These results suggest successes did a better job allocating time proactively - and perhaps efficiently - rather than that success was due to greater effort. This is consistent with the finding, for example, that a number of the controls mentioning dealing with Congress either discussed such dealings in a reactive way (stating they needed to be sensitive to congressional views) or expressed resentment at time demands these activities created. Reading the transcripts of interviews with controls, they seem to spend more time simply giving an account of the substantive content and progress of their initiatives, rather than discussing their interventions to increase chances of success.

\section{LIMITATIONS AND DISCUSSION}

Like any research, this study has limitations. One is the small number of respondents. The small number of respondents reflects the modest number of executives attempting major strategic change. Given the terms of our letter soliciting nominations and the number who responded to it, we could have received as many as 444 nominations of agency executives serving over a 16-year period; in fact we received 93, of the several thousand people as Senate-confirmed appointees over this timeframe. Even if the group we chose should be seen as (almost) a universe of those meeting our selection criteria, the danger exists that our findings are influenced by real randomness (as opposed to sampling error) in reported leader techniques.

\footnotetext{
45 Reported hours for successes and counterparts were remarkably similar, suggesting either common norms or common features within a given organization driving workweeks. In two of the six, responses were identical. For the other three cases, reports were 55 for the success and 70 for the counterpart, 60 and 70, 85 and 90, and 50 and 62.5. This within-agency consistency also supports the validity of these workweek estimates, which might be considered to be so contaminated by recall bias that the result that there were only small differences between the two groups might be seen as reflecting only noise.
} 
A second limitation is that we did no objective validation, say using trends in performance measures, of the extent to which these executives were indeed successful in achieving their goals. Furthermore, since the outside experts were not substantive experts on all of the agencies from which they nominated candidates, one possibility is that we are measuring only public relations or media skills rather than actual achievements.

We have two comments. It would have required a very information intensive investigation to examine others ways to measure success, and had we done so, subjective judgments still would have been necessary. For example, how much improvement (measured by performance metrics) would suffice to characterize a leader as successful; and what if there were improvement on some metrics but not others? So instead we performed a robustness check of nominations by asking insiders with substantive knowledge of each agency to judge the leader’s success on a 1-10 scale.

It is true that a Washington Post reporter rated the successes on average as better at effectively communicating their message to the media than was controls. However, the robustness check guards against the worry that the successes and failures succeeded or failed only in dealing with the media. Furthermore, we found (contrary to popular images) that working with the media was not a particularly prominent technique successes reported using. Finally, it should be noted that ability to communicate effectively, including with the media, may genuinely contribute to an executive's success by helping build both external and internal support for the leader's goals (Khademian 2002: 64), so media success should not be seen as orthogonal to substantive success.

A third limitation is that a possible explanation for the differences found here is that differences between the behaviors of the two groups reflect only that the successes 
did "more of everything” because their agenda was larger or more difficult than that of the counterparts. However, controls did not work less than the successes.

A final limitation is that we needed, due to a paucity of failure nominations, to resort to counterparts to create our control group. Thus, our results partly compare those successful at executing an ambitious vision with others whose agenda was more limited. To the extent a technique would be unnecessary for successfully executing a lessambitious agenda, failure to observe use of the technique by counterparts would not provide meaningful evidence about differentiators of the behaviors of our successes.

This raises the broader issue of whether it is possible to extend the reach of our results to draw conclusions about techniques associated with success at promoting good organization management in general. As noted earlier, there are research traditions emphasizing differences between "managers" who administer continuity and "leaders" who achieve transformation; or discuss tensions between "exploitative” and “exploratory” learning in organizations (March, 1999) and difficulties of organizational “ambidexterity” for successfully fielding existing and new products (Tushman and O’Reilly 2002), both involving management of continuity versus innovation. Also, some traditions in cognitive psychology (e.g. Gardner 1993; although this view is notundisputed, see e.g. Visser, Ashton, and Vernon 2006) suggest there are "multiple” intelligences, such that intelligence in one domain (e.g. change management) is not necessarily transferable to a different one (e.g. management of overall performance).

As noted, most of our hypotheses come from discussions in the literature about techniques associated with general good management. ${ }^{46}$ So, for most of these

\footnotetext{
${ }^{46}$ We note that some of the literature suggesting differences between the two contexts (for example, on ambidexterity or the exploitation/exploration tension) presents the tension in significant measure as
} 
techniques, it is appropriate to see whether counterparts used them, in pursuit of (more limited) agendas. ${ }^{47}$ It is also useful to compare successes with each other, to see which techniques successes used more, or less, frequently.

Because of worry about counterparts, especially for techniques hypothesized to be especially associated with leading change, we did examine failures separately, though the group size was very small. What we tended to find is that, for techniques associated with good general management failures behaved like counterparts, while for ones specifically associated with leading change, they behaved like successes. These intriguing results cause us to regard the small number of failures as a limitation of our results, since we would like to have a larger number of failure cases to get more evidence on this.

Despite any limitations, we believe these findings add to existing literature and also provide helpful advice to practitioners. While the observation that senior executives generally pay attention to interacting with Congress by itself simply reaffirms earlier studies of how these executives spend their time by scholars such as Bernstein or Kaufman, and would hardly surprise practitioners, we believe it is interesting, and not self-evident, empirically to discover there were differences between ways successful executives versus others engaged Congress. Our findings about techniques such as use of strategic planning, reorganization, and use of performance measures add evidence on issues about which there has been controversy both in the literature and among practitioners. The role that attention to creation of internal operating capacity by successful executives, even when seeking strategic change, is noteworthy, and ties to a

involving encouragement of innovation, often of new products for a firm, which has only limited relevance to any goal changes our executives sought, which did not involve wholly new, innovative ideas.

47 Indeed, to the extent counterparts were highly successful in achieving a more limited agenda and thus cannot appropriately be used as a control to examine use of these techniques on behalf of general good management, our results are biased downwards and hence conservative. 
debate among practitioners. Finally, following on the discussion above, we also regard one of our contributions as being to show support for a number of propositions generally discussed in the context of overall success in managing government agencies in the different context of execution of strategic change. 


\section{TABLE ONE: \\ TECHNIQUES USED BY SUCCESSES COMPARED WITH CONTROL GROUP, IN ORDER OF DIFFERENCE IN USE}

\begin{tabular}{|c|c|c|}
\hline & $\underline{\text { Successes }}$ & $\underline{\text { Controls }}$ \\
\hline Working with employee unions to gain support for goals & 2 & 0 \\
\hline Strategic planning & 6 & 1 \\
\hline Proactively working with interest groups & 5 & 1 \\
\hline Proactively working with the White House/OMB & 3 & 1 \\
\hline Proactively working with the media & 3 & 1 \\
\hline Developing slogans reflecting goals & 5 & 2 \\
\hline Using performance measures & 6 & 3 \\
\hline Reorganization & 6 & 3 \\
\hline $\begin{array}{l}\text { Relationship building with external constituencies and/or } \\
\text { employees }\end{array}$ & 4 & 2 \\
\hline $\begin{array}{l}\text { Using period between nomination and confirmation to } \\
\text { think about goals/gather information }\end{array}$ & 4 & 2 \\
\hline $\begin{array}{l}\text { Collaborative/participatory management style with } \\
\text { employees }\end{array}$ & 7 & 4 \\
\hline Proactively working with Congress & 6 & 4 \\
\hline Establishing an accountability system & 3 & 2 \\
\hline Appealing to public service motivation & 5 & 5 \\
\hline Changes in budget allocations to reflect goals & 2 & 2 \\
\hline Working to communicate goals to employees & 3 & 4 \\
\hline
\end{tabular}

NB: There were eight successes and nine in the control group. 
TABLE TWO:

MOST-FREQUENTLY USED TECHNIQUES THE SUCCESSES DISCUSSED (N=8)

\section{7 mentions}

Collaborative/participatory management style with employees

\section{6 mentions}

Strategic planning

Proactively working with Congress

Using performance measures

Reorganization

\section{5 mentions}

Proactively working with interest groups

Appealing to public service motivation

Developing slogans reflecting goals

\section{4 mentions}

Relationship building with external constituencies and/or employees

Using period between nomination and confirmation to think about goals/gather

information

\section{3 mentions}

Proactively working with the White House/OMB (**)

Proactively working with media

Establishing an accountability system

Working to communicate goals to employees

\section{2 mentions}

Changes in budget allocations to reflect goals

Working with employee unions to gain support for goals

$\left.{ }^{* *}\right)$ Based on 7 possible mentions, rather than 8 (see text for explanation) 
TABLE THREE:

POLITICAL APPOINTEES AS A PERCENTAGE OF ALL MANAGERS IN AGENCIES WITH SUCCESSFUL LEADERS

$\begin{array}{cl}\text { Agency A } & 0.00 \% \\ \text { Agency B } & 0.01 \% \\ \text { Agency C } & 0.02 \% \\ \text { Agency D } & 0.09 \% \\ \text { Agency E } & 0.2 \% \\ \text { Agency F } & 0.2 \% \\ \text { Agency G } & 0.2 \% \\ \text { GOVERNMENT AVERAGE } & \\ \text { (Civilian Agencies) } & 1.5 \% \\ \text { Agency H } & \\ \text { Agency I } & 2.6 \% \\ \end{array}$

Source: Lewis (2008), supplemented by agency-provided data. This is the broader group of agencies; see footnote 17. Data is for the year following the leader's assumption of office

\section{TABLE FOUR: \\ TECHNIQUES USED BY LEADERS IN LEADERSHIP AND INNOVATION (N=7)}

Proactively working with legislature 5

Attention to development of operating capacity (general) 5

Develop slogans reflecting goals 4

Proactively working with interest groups 3

Proactively working with media 3

Proactively working with top executive leadership 3

Appealing to public service motivation 3

Strategic planning 2

Cultivate general public support 2

Collaborative/participatory management style with employees 2 


\section{REFERENCES}

Ansoff, H. I. 1965. Corporate strategy. New York, NY: McGraw-Hill.

Bardach, Eugene. 1998. Getting agencies to work together: The practice and theory of managerial craftsmanship. Washington, DC: Brookings Institution Press.

Behn, Robert D. 1988. Management by groping along. Journal of Policy Analysis and Management 7 (4): 643-63.

Behn, Robert D. 2001. Rethinking democratic accountability. Washington, DC: Brookings Institution Press.

Bernstein, Marver H. 1958. The job of the federal executive. Washington, DC: Brookings Institution.

Borins, Sandford F. 1998. Innovating with integrity: How local heroes are transforming American government. Washington, DC: Georgetown University Press.

Boyd, Brian K. 1991. Strategic planning and financial performance: A meta-analytic review. Journal of Management Studies 28 (4): 353-74.

Boylan, Richard T. 2004. Salaries, turnover, and performance in the federal criminal justice system. Journal of Law and Economics XLVII : 75-92.

Brewer, Gene A. 2008. Employee and organizational performance. In Motivation in public management: The call of public service., eds. James L. Perry, Annie Hondeghem, 136-156. New York: Oxford University Press.

Coch, Lester, and John R. P. French Jr. 1948. Overcoming resistance to change. Human Relations 1: 419-28.

Cohen, David M. 1998. Amateur government. Journal of Public Administration Research and Theory 8 (4): 450-97.

Cyert, Richard M., and James G. March. 1963. Behavioral theory of the firm. Englewood Cliffs, NJ: Prentice Hall.

Cyert, Richard Michael, and James G. March. 1963. A behavioral theory of the firm. Prentice-Hall international series in management. Englewood Cliffs, N.J.: PrenticeHall.

Doig, Jameson W., and Erwin C. Hargrove. 1990. Leadership and innovation, eds. Jameson W. Doig, Erwin C. Hargrove. Abridged Edition ed. Baltimore, MD: Johns Hopkins University Press. 
Fayol, Henri. 1949. General and industrial management. London: Pitman.

Fernandez, S., and H. G. Rainey. 2006. Managing successful organizational change in the public sector. Public Administration Review 66 (2): 168-76.

Fesler, James W. 1987. The Brownlow Committee fifty years later. Public Administration Review 47 (4): 291-95.

Floyd, Steven W., and Peter J. Lane. 2000. Strategizing throughout the organization: Managing role conflict in strategic renewal. Academy of Management Review 25 (1): 154-77.

Gardner, Howard. 1993. Frames of mind: The theory of multiple intelligences. 10th edition ed. New York, NY: Basic Books.

Gilmour, John, and David E. Lewis. 2006. Assessing performance budgeting at OMB: The influence of politics, performance, and program size in FY 2005. Journal of Public Administration Research and Theory 16 (2): 169-86.

Golden, Olivia. 1990. Innovation in public sector human services programs: The implications of innovation by 'groping along.'. Journal of Policy Analysis and Management 9 (2): 219-48.

Gulick, Luther Halsey, and Lyndall F. Urwick. 1937. Papers on the science of administration. New York: Institute of Public Administration, Columbia University.

Hammer, Michael, and Steven A. Stanton. 1995. The reengineering revolution: A handbook. New York, NY: Harper Business.

Hatry, Harry P., and Joseph S. Wholey. 1999. Performance measurement: Getting results. Washington, DC: Urban Institute Press.

Herman, Robert D., and Dick Heimovics. 1994. Executive leadership. In The Jossey-Bass handbook of nonprofit leadership and management., ed. Robert D. Herman, 137149. San Francisco, CA: Jossey-Bass.

Heymann, Philip B. 1987. The politics of public management. New Haven, CT: Yale University Press.

Horton, Sylvia. 2008. History and persistence of an idea and an ideal. In Motivation in public management: The call of public service., eds. James L. Perry, Annie Hondeghem, 17-32. New York: Oxford University Press.

Jarysiszynx, Philip, and et al. 1986. Chief executive background and firm performance. In The uneasy alliance: Managing the productivity-technology dilemma., eds. Kim B. Clark, et al., 127-?. Boston, MA: Harvard Business School Press. 
Kaplan, Robert S., and D. P. Norton. 2001. The strategy-focused organization: How balanced scorecard companies thrive in the new business environment. Boston, MA : Harvard Business School Press.

Kaplan, Robert S., and David P. Nortong. 2006. How to implement a new strategy without disrupting your organization. Harvard Business Review(March).

Kaplan, Sarah. 2008. Cognition, capabilities, and incentives: Assessing firm response to the fiber-optic revolution. Academy of Management Journal 51 (4): 672-95.

Kaplan, Steven N., and Bernadette A. Minton. 2006. How has CEO turnover changed? increasingly performance sensitive boards and increasingly uneasy CEOs. NBER Working Paper.

Kaufman, H. 2006. The forest ranger: A study in administrative behavior. Resources for the Future.

Kaufman, Herbert. 1981. The administrative behavior of federal bureau chiefs. Washington, DC: Brookings Institution Press.

Keeney, Ralph L., and Howard Raiffa. 1976. Decisions with multiple objectives: Preferences and value tradeoffs. New York: John Wiley \& Sons.

Kelman, Steve. 2007. Public administration and organization studies. The Academy of Management Annals: Volume 1.

2006. Downsizing, competition, and organizational change in government: Is necessity the mother of invention. Journal of Policy Analysis and Management 25, (4): 875-895.

- 2005. Unleashing change: A study of organizational renewal in government. Washington, DC: Brookings Institution Press.

Kelman, Steven J. 2006. Book review essay: 9/11 and the challenges of public management: The 9/11 Commission report: Final report of the National Commission on Terrorist Attacks Upon the United States. National Commission on Terrorist Attacks. Administrative Science Quarterly 51 (1): 129-42.

Kelman, Steven J., and John N. Friedman. 2009. Performance improvement and performance dysfunction: An empirical examination of impacts of the emergency room wait-time target in the English National Health Service. Journal of Public Administration Research and Theory Forthcoming, .

Kesner, Idalene F., and Terrence C. Sebora. 1994. Executive succession: Past, present \& future. Journal of Management 20 (2): 327-72. 
Khademian, A. M. 2002. Working with culture: The way the job gets done in public programs. Washington, DC: CQ Press.

Kotter, John P. 1996. Leading change. Boston, MA: Harvard Business School Press. 1990. A force for change: How leadership differs from management. New York, NY: Free Press.

Lewin, Kurt. 1958. Group decision and social change. In Readings in social psychology., eds. Eleanor E. Maccoby, Theodore M. Newcomb and Eugene L. Hartley. 3rd. Edition ed., 197-211. New York: Holt, Rinehart and Winston.

Lewis, David E. 2008. The politics of presidential appointments: Political control and bureaucratic performance. Princeton, NJ: Princeton University Press.

_ 2007. Testing Pendleton's premise: Do political appointees make worse bureaucrats? Journal of Politics 69 (4): 1073-88.

Light, Paul C. 2008. A government ill executed: The decline of the federal service and how to reverse it. Cambridge, MA: Harvard University Press.

— 1995. Thickening government: Federal hierarchy and diffusion of Accountability . Washington, DC: Brookings Institution Press.

Light, Richard J., Judith D. Singer, and John B. Willett. 1990. By design : Planning research on higher education. Cambridge, Mass.: Harvard University Press.

Likert, Rensis. 1961. New patterns of management. New York: McGraw-Hill.

Lindblom, Charles E. 1965. The science of "muddling through.” Public Administration Review 19 (2): 79-88.

Lynn, L. 1996. Public management as art, science, and profession. Chatham, NJ: Chatham House Publishers.

Maranto, Robert. 1993. Politics and bureaucracy in the modern presidency. Greenwood.

March, James G. 1999. The pursuit of organizational intelligence. Malden, MA: Blackwell Publishers.

March, James G., and Johan P. Olsen. 1983. Organizing political life: What administrative reorganization tells us about government. American Political Science Review 77 (2): 281-96.

McGregor, Douglas. 1960. The human side of enterprise. New York: McGraw-Hill. 
McLean, Iain, Dirk Haubrich, and Roxana Gutierrez-Romero. 2007. The perils and pitfalls of performance measurement: The CPA regime for local authorities in England. Public Money \& Management (April): 111-7.

Miles, Matthew B., and A. Michael Huberman. 1994. Qualitative data analysis: An expanded sourcebook, 2nd edition. Thousand Oaks, CA: Sage.

Miller, Gary J. The political evolution of principal-agent models. Annual Review of Political Science 8 (1): 203-25.

Mintzberg, Henry. 1994. The rise and fall of strategic planning. New York, NY: The Free Press.

Moe, Terry M. 1985. The politicized presidency. In The new direction in American politics., eds. J. E. Chubb, P. E. Peterson. Washington, DC: Brookings Institution Press.

Moore, Mark H. 1995. Creating public value: Strategic management in government. Cambridge, MA: Harvard University Press.

Moynihan, D. P. 2008. The dynamics of performance management: Constructing information and reform. Washington, DC: Georgetown University Press.

Nathan, Richard P. The administrative presidency. Hoboken, NJ: John Wiley \& Sons.

Office of Personnel Management. 2007. FedScope: Federal Human Resources Data (Dec. 2007) As of Dec. 2007, latest available data.

http://www.fedscope.opm.gov/employment.asp and http://www.fedscope.opm.gov/cognos/cgi-bin/ppdscgi.exe?DC=Q\&E=/FSe\%20\%20Status/Employment\%20-\%20December\%202007\&LA=en\&LO=enus\&BACK=/cognos/cgi-bin/ppdscgi.exe?toc=\%2FFSe\%20-\%20Status\&LA=en\&LO=en$\underline{\text { uS }}$

Partnership for Public Service. 2008. Roadmap to reform: A management framework for the next administration. Booz Allen \& Hamilton.

Perry, James L., and Annie Hondeghem, eds. 2008. Motivation in public management: The call of public service. New York: Oxford University.

Perry, James L., and Kenneth L. Kraemer, eds. 1983. Public management: Public and private perspectives. Palo Alto, CA: Mayfield Publishing Company.

Porter, Michael E. 1996. What is strategy? Harvard Business Review (November December).

Powell, Thomas C. 1992. Organizational alignment as competitive advantage. Strategic Management Journal 13 (2): 119-34. 
Quinn, J. B. 1980. Strategies for change: Logical incrementalism. Homewood, IL: RD Irwin.

Radin, Beryl. 2006. Challenging the performance movement.

Rainey, H. G., and P. Steinbauer. 1999. Galloping elephants: Developing elements of a theory of effective government organizations. Journal of Public Administration Research and Theory 9 (1): 1-32.

Seidman, Harold, and Robert S. Gilmour. 1970. Politics, position, and power. New York: Oxford University Press.

Stokey, Edith, and Richard Zeckhauser. 1978. A primer for policy analysis. New York, NY: Norton.

Strauss, Anselm L., and Juliet M. Corbin. 1998. Basics of qualitative research: Techniques and procedures, 2nd ed. Thousand Oaks, CA: Sage Publications.

Thomas, C. W. 1993. Reorganizing public organizations: Alternatives, objectives, and evidence 1. Journal of Public Administration Research and Theory 3 (4): 457-86.

Tushman, Michael L., and Charles A. O'Reilly. 2002. Winning through innovation: A practical guide to leading organizational change and renewal. Boston, MA: Harvard Business School Press.

Visser, B. A., M. C. Ashton, and P. A. Vernon. 2006. Beyond g: Putting multiple intelligences theory to the test. Intelligence 34 (5): 487-502.

Vroom, Victor H., and Arthur G. Jago. 1988. The new leadership: Managing participation in organizations. Englewood Cliffs, NJ: Prentice-Hall.

Wade, J. B., J. F. Porac, and T. G. Pollock. 1997. Worth, words, and the justification of executive pay. Journal of Organizational Behavior 18 (Special Issue): 641-64.

Weick, Karl E. 1984. Small wins: Redefining the scale of social problems. The American Psychologist 39 (1): 40-9.

Wildavsky, Aaron B. 1974. The politics of the budgetary process. Boston, MA: Little, Brown.

Wilson, James Q. 1989. Bureaucracy: What government agencies do and why they do it. New York, NY: Basic Books.

Yukl, Gary. 2001. Leadership in organizations. 5th ed. Upper Saddle River, NJ: PrenticeHall. 